\title{
The Impact of Jogging on the Improvement of Physical Fitness
}

\author{
A Agus $^{1 *}$, M P Sari ${ }^{1}$ \\ ${ }^{1}$ Faculty of Sport Science, Universitas Negeri Padang, Indonesia \\ "Corresponding author. Email: apriagusfik@gmail.com
}

\begin{abstract}
The aim of this study was to determine the effect of jogging to enhance the physical fitness of students in Sport Science Department, Universitas Negeri Padang. Quasi-experiment study was used in this research. The sample of this research was 20 students taken through purposive sampling technique. Data were taken with an instrument of Rockport run 1600 meters, and analyzed with comparative test (t-test) and significant level of $5 \%$. results of the study: the level of students' physical fitness before treatment is 45.40 , and after receiving treatment is 50.35. The result of t-test is tobserved(4.25) >ttable(1.73). In conclusion, there is a significant impact of jogging on the improvement of physical fitness of students in Sports Science Department of Universitas egeri Padang.
\end{abstract}

Keywords: Jogging, physical fitness

\section{INTRODUCTION}

Caspersen, Powell, \& Christenson (1985) distinguished the definitions of physical activity, exercise, and physical fitness. Physical activity can be defined as bodily movement produced by skeletal muscles (either categorized as occupational, sports, conditioning, household, or other activities) that consume energy which can be measured in kilocalories. Meanwhile exercise is defined as a subset of physical activity that is planned, structured, repetitive, and has as a final or an intermediate objective to improve or maintain physical fitness. Subsequently, physical fitness is defined as a set of attributes that are either health- or skill-related which can be measured with specific tests. By this definition, we would like to define jogging in this research as a subset of programmed and repetitive physical activity that has a final goal to improve physical fitness.

Deuster \& Silverman (2013) stated that physical fitness is one pathway toward resilience because regular exercise and/or physical activity induce positive physiologic and psychological benefits, protects against the potential consequences of stressful events, and prevents many chronic diseases. Physical fitness depicts one's temporary physical quality after doing programmed exercise. Irianto (2003) defines physical fitness as one's ability to do daily activities efficiently without having too much tiredness and can still enjoy one's spare times. Everybody dreams of having a healthy and fit body that they assume that through sports activities such as aerobic, they will manage to fulfil the dream. People's awareness to improve health and fitness is growing better nowadays. Such improvement in health and fitness level will benefit people in daily activities that no matter what the activities are, they will manage to do it well. In fact, Warburton, Nicol, \& Bredin (2006) stated that there is a linear relation between physical activity and health status, such that a further increase in physical activity and fitness will lead to additional improvements in health status.

People's expectation of having good physical fitness by doing more physical activities is in accordance with government's expectation which was written in the Act of National Sports System No. 3 in 2005 Chapter II article 4 which states that:

"Sports aim to maintain and improve health and fitness, achievement, human quality, to embed moral values and noble character, sportiveness, discipline, to strengthen and to nurtures the unity of nation, to strengthen the national defense, and also to lift up nation's dignity and honor".

Recently, people in societies have begun to be aware to improve their physical fitness, as can be seen from the many sports activities that people are now like to participate, such as aerobic on the weekends, cycling, green walk, marathon, and so on. This could have something to do with the growing concerns of major public health for teenage and young adults today and in the future which is the combination of increasing body fatness together with decreasing physical fitness (Kyröläinen, Santtila, Nindl, \& Vasankari, 2010b). As we can hear and see in mass media, more and more people choose to spend their time in weekend mornings in public places with facilities for physical activities. For instance, several big cities in Indonesia such as 
Jakarta, Tangerang, and Bandung have Car Free Day on Sundays. Here in Padang city too, people at all ages usually gather in Sports Arena of Haji Agus Salim on weekends.

Based on our observation on the field about the growth of fitness sports in Padang city, people choose sports activities such as walking, cycling, jogging, or aerobics to improve their fitness. There are many reasons behind people's eagerness to participate in these sports activities of course. One of them could be in accordance with what Garber et al., (2011) stated that the beneficial effects of exercise are indisputable, and the benefits of exercise far outweigh the risks in most adults. Siddiqui, Nessa, \& Hossain (2010) stated that regular exercise improves the cardiovascular status, reduces the risk of cardiac disease, high blood pressure and cerebrovascular disease, reduces body weight, improves insulin sensitivity, helps in glycemic control, prevents obesity and diabetes mellitus, and It is helpful for relieving anxiety, stress, brings a sense of wellbeing and overall physical fitness. In addition, Pollock, Feigenbaum, \& Brechue (1995) also stated that physical activity is important for fitness; and has been shown to significantly reduces the risk of morbidity and mortality from coronary artery disease (CAD); and to improve both the quality of life and longevity.

Garber et al., (2011) suggested that a program of regular exercise which includes cardiorespiratory, resistance, flexibility, and neuro motor exercise beyond daily activities is essential for most adults to improve and maintain physical fitness and health. Haskell et al., (2007) suggested that to improve and maintain health, all healthy adults aged 18 to 65 years old need to do moderate-intensity aerobic (endurance) activity for a minimum of 30 minutes on five days each week or vigorous-intensity aerobic activity for a minimum of 20 min on three days each week. Physical activity and cardiorespiratory fitness are associated with improved cardiovascular health and reduced all-cause mortality (Minder et al., 2014). There is evidence that aerobic physical activities which improve cardiorespiratory fitness are beneficial for cognitive function in healthy older adults, with effects observed for motor function, cognitive speed, auditory and visual attention (Angevaren, Aufdemkampe, Verhaar, Aleman, \& Vanhees, 2008).

Numerous studies have shown the benefit of doing regular physical activities to human's life in all ages. However, based on a survey conducted in 2016, it was found that most people in Padang city do not know well about how to do aerobic sports so that the impact doesn't meet their expectations. Everybody seems to assume that what they do could improve physical fitness but in general they have never done any fitness test. Thus, it is difficult to see the impact of any sports activities that they have done.
The Ministry of Health of Indonesian Republic (2012) recommended jogging, walking, and cycling as forms of exercise to improve physical fitness because they enables the heart rate to go up and down with stability. On the other hand, a cooperative study between Spanish government and Health Department of Indonesian Republic (2012) has found that one benefit from jogging is that it burns calories more than walking does. This finding is contradictive with what Greiwe \& Kohrt (2000) has found that walking at speeds $>$ or $=8.0$ $\mathrm{km} . \mathrm{hr}(-1)$ resulted in rates of energy consumption that were as high or higher than jogging at the same speeds. Also, the higher rates of energy consumption during walking as compared to jogging at speeds greater than $8.0 \mathrm{~km} . \mathrm{hr}(-1)$ were associated with higher heart rates, RER, RPE and plasma lactate response.

Deny (2017) conducted a study by comparing the impact of jogging exercise and extensive interval method on physical fitness, and found that extensive interval method gave better impact on physical fitness. However, this result contained a little bias since the treatments of both sample groups were different. The group with extensive interval method was controlled better than the group with jogging exercise. On the other hand, a study conducted by Milburn \& Butts (1983) compared the effect of aerobic dance and jogging on female students and found out that both exercises significantly increase students' $\mathrm{VO}_{2} \mathrm{Max}$. Despite this difference, since $\mathrm{VO}_{2} \mathrm{Max}$ is related to physical fitness, it is safe to say that jogging could improve physical fitness.

Jogging itself has many undebatable benefits as a form of physical exercise. Nabkasorn et al. (2006) suggested that jogging exercise could be effective in improving depressive state, hormonal response to stress and physiological fitness of adolescent females with depressive symptoms. Grissom (2005) worked with more than 800.000 students in public schools in California, and found that there is a positive relationship between physical fitness and academic achievement, that is when physical fitness scores improved, the mean of academic achievement is also improved.

As a part of society, students in Sports Science Department could be representatives of people in Padang city. Just like other people, these students have many activities scheduled everyday which require good stamina to go through each activity without having too much tiredness. This good stamina is possible with good level of physical fitness. Despite the benefits of physical activity to human being, a study from Kilpatrick, Hebert, \& Bartholomew (2005) found that only $38 \%$ of college students participate in regular vigorous activity, and only $20 \%$ participate in regular moderate activity, and furthermore, almost half of all college students report a decrease in physical activity following graduation. In addition, collective studies 
examining physical fitness profiles of young men suggest a disturbing worldwide trend of decreased aerobic fitness and increased obesity (Kyröläinen, Santtila, Nindl, \& Vasankari, 2010a). Here we have the contradiction. Following graduation is the time where students should focus more on finishing their study. This focus of course will consume energy and require good stamina or good physical fitness. However, with the tendency of decreasing physical activity, this physical fitness could be difficult to achieve. It is also possible that students' physical condition could deteriorate after graduation.

Previous finding is consistent with our finding prior to this research. We conducted a test of physical fitness to all students in Sports Science Department of Universitas Negeri Padang who took Sports Fitness course in the first semester of 2016/2017 academic year. Based on the test, we found that more than $60 \%$ of all students have low level of physical fitness, which could possibly be related to their physical activity. The result of this physical fitness test and supported by the result of the survey in 2016 have brought us to research the effectiveness of jogging exercise to improve physical fitness. Since it was difficult to find members of societies in Padang city who could afford the time to participate as our research subjects, we decided to work with students in Sports Science Department of Universitas Negeri Padang.

\section{METHOD}

Quasi-experiment study was used in this research with one group pretest-posttest design. This method was chosen since we seek to find the impact of jogging exercise, as Arikunto (2007) stated that experiment method is a method to find whether there is an impact or not on the subject of research due to given treatment. The sample of this research was 20 students enrolled in Sports Science Department which were chosen through purposive sampling technique. Meanwhile, the population of this research is all students who enrolled in Sport Fitness course in first semester of 2017/2018 academic year (215 students in total).

The pretest and posttest of students' hemoglobin level was conducted in the Laboratory of Sports Science Department, Universitas Negeri Padang, and the treatment was given on the running track of the laboratory. Data were taken with an instrument of Rockport run test of 1600 meters. Originally, Rockport Test is a sub-maximal field test to estimate $\mathrm{VO}_{2} \mathrm{max}$ in males and females aged 20 to 69 years old, in which the participant is required to walk one mile (1.6 kilometers) as quickly as possible (Canadian Society for Exercise Physiology, 2010). In this study, we modified the test a little bit. Since our subjects are young, instead we asked them to run 1.6 kilometers. This test is suitable to see the endurance of the heart and the respiratory system.
In order to do the test, there are several thing should be prepared first, such as: flat running track, stopwatch, whistle, and stationaries. There were two assistants helped us taking the data, one was taking the score and the other one was recording the time. All subjects in this research took the test in sports outwears, and were required to do warm-up for ten minutes. As soon as they heard the whistle sound, they started running and then stopped when they reached 1600 meters. The time they took to reach this distance was taken as the result of the test.

We planned to do direct measurement of maximum oxygen uptake $\left(\mathrm{VO}_{2} \max \right)$ as the standard index of cardiorespiratory fitness, however this is only practical is laboratory settings (Siconolfi et al., 1982). Therefore, we use a benchmark for the test result. We referred to the standardized norms of $\mathrm{VO}_{2} \mathrm{Max}$ published by BKOM (2007) as can be seen in Table 1 below. This benchmarking is in accordance with Pollock, Feigenbaum, \& Brechue, (1995) that physical activity such as jogging- increases functional capacity through improvements in maximal oxygen consumption $\left(\mathrm{VO}_{2} \mathrm{max}\right)$, body composition, muscular strength and endurance, and flexibility. Therefore, measuring $\mathrm{VO}_{2} \mathrm{max}$ is essential in finding out ones' physical fitness level. Meanwhile, to level of physical fitness were categorized based on the running times which were converted into the value of $\mathrm{VO}_{2} \mathrm{Max}$, and then were referred to the table of norms below. Data were described then analyzed with comparative test (t-test) and significant level of 5\%. The hypothesis was tested using descriptive inferential statistics with t-test formula

\section{RESULT AND DISCUSSION}

The result of pretest and posttest of students' physical fitness gave the highest $\mathrm{VO}_{2} \mathrm{Max}$ of 56 and the lowest one of 32, meanwhile the average value of $\mathrm{VO}_{2} \mathrm{Max}$ was 45.30 and the value of Standard Deviation was 5.38. After receiving 18 treatments, out of the 20 students as research subjects, the highest value of $\mathrm{VO}_{2} \mathrm{Max}$ was found to be 57 and the lowest one to be 50.35. The average value and the standard deviation were 50.35 and 5.47 respectively. The overall result can be seen in Table 4 below. 
Table 1. Distribution of Frequency of Students' Physical Fitness

\begin{tabular}{ccccccc}
\hline $\begin{array}{c}\text { ata of } \\
\text { Joggin } \\
\text { g }\end{array}$ & $\mathbf{n}$ & $\begin{array}{c}\text { Me } \\
\text { an }\end{array}$ & $\begin{array}{c}\mathbf{t}_{\text {obser }} \\
\text { ved }\end{array}$ & $\begin{array}{c}\mathbf{t}_{\text {tab }} \\
\text { le }\end{array}$ & $\begin{array}{c}\text { Differe } \\
\text { nce }\end{array}$ & $\begin{array}{c}\text { Percenta } \\
\text { ge of } \\
\text { Improve } \\
\text { ment } \\
\text { ice }\end{array}$ \\
& & & & & & \\
Pretes & 2 & 45.3 & 4.25 & 1.7 & 5.05 & 11.15 \\
$\mathbf{t}$ & 0 & 0 & & 3 & & \\
Postte & 50.3 & & & & \\
st & 5 & & & & \\
\hline
\end{tabular}

Table 4 shows that only one students fall into Less category, with class interval of $\mathrm{VO}_{2} \mathrm{Max} 25-33$ and relative frequency 5\%. Meanwhile, at the Excellent category, only two students manage to get the value of $\mathrm{VO}_{2} \mathrm{Max}$ more than 53 , with relative frequency of $10 \%$. Compared to the posttest result, the lowest class interval is $34-42$ (higher than the pretest result), and the number of students is $2(10 \%)$ and the category of physical fitness is Average. This improvement is also can be seen in class interval of $34-42$ and $>53$. The number of students is greater than those in pretest result.

Before testing the hypothesis of this research with ttest, we ran normality test for both pretest and posttest score with Liliefors test with significant level of 5\%. The criteria of this test is that the data is called normally distributed if the $\mathrm{L}_{\text {observed }}$ is lower than the $\mathrm{L}_{\text {table }}$ at significant level of $5 \%$. Table 5 below shows the result of Liliefors test on pretest and posttest scores.

Table 2. The Result of Normality Test (Liliefors Test)

\begin{tabular}{ccccc}
\hline $\begin{array}{c}\text { Data of } \\
\text { Jogging }\end{array}$ & $\mathbf{n}$ & Lobserved $_{\text {Lable }}$ & Interpretation \\
Exercise & & & & \\
\hline Pretest & 20 & 0.0517 & 0.1920 & Normal \\
Posttest & & 0.0336 & & \\
\hline
\end{tabular}

After confirming that both data were normally distributed, we conducted the t-test to test the hypothesis. The statement of research hypothesis is that there is a significance impact of jogging exercise on students' physical fitness. The criteria for this test is that we can accept the hypothesis if the value of $t_{\text {observed }}$ $>t_{\text {table }}$ at significance level of $5 \%$. Our calculation gave the value of $\mathrm{t}_{\text {observed }} 4.25$ which is greater than $\mathrm{t}_{\text {table }} 1.74$ for $\mathrm{n}=20$. More result is provided in Table 6 below.
Table 3. The Result of t-test on pretest and posttest scores of Students' Physical Fitness

\begin{tabular}{|c|c|c|c|c|c|c|}
\hline \multirow{2}{*}{$\begin{array}{l}\text { N } \\
\text { o. }\end{array}$} & \multirow{2}{*}{$\begin{array}{c}\text { Class } \\
\text { Interv } \\
\text { al }\end{array}$} & \multicolumn{2}{|c|}{ Pretest score } & \multicolumn{2}{|c|}{ Posttest score } & \multirow{2}{*}{$\begin{array}{l}\text { Level } \\
\text { of } \\
\text { Physic } \\
\text { al } \\
\text { Fitnes }\end{array}$} \\
\hline & & $\begin{array}{c}\text { Absol } \\
\text { ute } \\
\text { freq. }\end{array}$ & $\begin{array}{l}\text { Relati } \\
\text { ve } \\
\text { freq. }\end{array}$ & $\begin{array}{c}\text { Absol } \\
\text { ute } \\
\text { freq. }\end{array}$ & $\begin{array}{l}\text { Relati } \\
\text { ve } \\
\text { freq. }\end{array}$ & \\
\hline 1 & $>53$ & 2 & 10.00 & 4 & 20.00 & $\begin{array}{l}\mathbf{S} \\
\text { Excelle } \\
\text { nt }\end{array}$ \\
\hline 2 & $\begin{array}{c}42- \\
52\end{array}$ & 13 & 65.00 & 14 & 70.00 & Good \\
\hline 3 & $\begin{array}{c}34- \\
42\end{array}$ & 4 & 20.00 & 2 & 10.00 & $\begin{array}{c}\text { Averag } \\
\mathrm{e}\end{array}$ \\
\hline 4 & $\begin{array}{c}25- \\
33\end{array}$ & 1 & 5.00 & 0 & 0.00 & Less \\
\hline 5 & $<25$ & 0 & 0.00 & 0 & 0.00 & $\begin{array}{l}\text { Very } \\
\text { Less }\end{array}$ \\
\hline
\end{tabular}

All the tests conducted in this research brought us to understand that the programed jogging exercise (in this case, 3 weeks long) helped to improve the physical fitness significantly. These results also proved that doing sports regularly gives a lot of benefits to our body. In accordance with what Sharkey (2003) stated related to health and long life that regular sports is one of many activities that can extend life up to 11 years long for men and 7 years for women. Even though Sharkey (2003) did not elaborate in detail how to calculate the life extension, but he did suggested sport activities to extend life, namely: walking, running, weightlifting, jogging, cycling, and swimming for 90 minutes. Sharkey (2003) furthermore added that the benefits of doing sports regularly are: 1) reducing anxiety, 2) reducing depression in light and average level, 3) relieving stress, and 4) good emotional impacts for all ages.

Brandes (2012) proposed that the decline of physical activity is considered to play an important role in the deterioration of health predictors, such as overweight, and the associated increase of cardiovascular and all-cause mortality. Garatachea \& Lucia (2013) found that in elderly people, functional independence is directly dependent on physical fitness, and ageing is inevitably associated with the declining functions of systems and organs (heart, lungs, blood vessels, skeletal muscles) that determine physical fitness. Thus, age-related diminished physical fitness contributes to the development of sarcopenia, frailty or disability, all of which severely deteriorate independent living and thus quality of life. These findings lead us to see the need to improve physical activity. Kyröläinen et al., (2010a) also emphasized the need for continuous efforts to foster improved physical fitness and healthy lifestyles should be encouraged to combat the trends of decreasing physical activity among college students.

In addition, McGowan and William (1997) stated that walking, jogging, cycling, and swimming are all 
good aerobic form of exercises. Furthermore, if we take a closer look, jogging can be categorized as an activity with high impact but low possibility of accident. Hoffman (1984) defined jogging or running as a key for physical fitness, which means even though other forms of aerobic activities also as good in promoting physical fitness, jogging is particularly special because it holds the key to it. Jogging exercise is easy to do, not expensive, does not require particular equipment, and can be done anytime anywhere.

However, with all benefits that jogging has to offer, Sadoso (1990) did suggest that a good started for this exercise is three times in a week, 30 minutes long each time. Better way to start jogging exercise was suggested by Afriwardi (2010), such as: 1) warm-up 5-10 minutes; 2) core exercise 30 - 60 minutes; 3) try to achieve Target Heart Rate; 4) cool-down 5-10 minutes; and 5) stretching.

\section{CONCLUSIONS}

The analysis of data in this result bring us to conclude that programmed jogging exercise is really good to improve and to maintain the level of students' physical fitness, as can be seen from the t-test result, where $t_{\text {observed }} 4.25$ is greater than $t_{\text {table }} 1.73$ for number of sample as much as 20 and significance level of $5 \%$. Based on this result, we would like to suggest students in Sports Science Department to do jogging in regular basis to improve and to maintain the level of physical fitness which is also give benefit to life. We would also like to suggest people in societies to do jogging as the best way to improve physical fitness. This suggestion can also go to all people who wish to improve physical fitness. One point to be remembered is that to do jogging exercise by following the steps suggested by experts to get maximum result out of it.

\section{REFERENCES}

[1] Angevaren, M., Aufdemkampe, G., Verhaar, H. J. J., Aleman, A., \& Vanhees, L. (2008). Physical activity and enhanced fitness to improve cognitive function in older people without known cognitive impairment. The Cochrane Database of Systematic Reviews, (3), CD005381.

https://doi.org/10.1002/14651858.CD005381.pu b3

[2] Brandes, M. (2012). The importance of physical activity and fitness for human health. Bundesgesundheitsblatt - Gesundheitsforschung - Gesundheitsschutz, 55(1), 96-101. https://doi.org/10.1007/s00103-011-1395-x

[3] Canadian Society for Exercise Physiology. (2010). The Rockport One Mile Walking Test. The Canadian Physical Activity, Fitness and Lifestyle Approach Supplement to the Third
Edition, s9.

[4] Caspersen, C. J., Powell, K. E., \& Christenson, G. M. (1985). Physical activity, exercise, and physical fitness: definitions and distinctions for health-related research. Public Health Reports (Washington, D.C. : 1974), 100(2), 126-131. https://doi.org/10.2307/20056429

[5] Deny, Suryana R. 2017. Difference of Impact of Jogging and Extensive Interval method on Physical Fitness of Students In Sports Science Department Universitas Negeri Padang. Undergraduate Thesis.

[6] Deuster, P. A., \& Silverman, M. N. (2013). Physical Fitness: A Pathway to Health and Resilience. US Army Medical Department Journal, 13(4), 24-35.

[7] Garatachea, N., \& Lucia, A. (2013). Genes, physical fitness and ageing. Ageing Research Reviews. https://doi.org/10.1016/j.arr.2012.09.003

[8] Garber, C. E., Blissmer, B., Deschenes, M. R., Franklin, B. A., Lamonte, M. J., Lee, I. M., ... Swain, D. P. (2011). Quantity and quality of exercise for developing and maintaining cardiorespiratory, musculoskeletal, and neuromotor fitness in apparently healthy adults: Guidance for prescribing exercise. Medicine and Science in Sports and Exercise, 43(7), 13341359.

https://doi.org/10.1249/MSS.0b013e318213fefb

[9] Greiwe, J. S., \& Kohrt, W. M. (2000). Energy expenditure during walking and jogging. Journal of Sports Medicine and Physical Fitness, 40(4), 297-302.

[10] Grissom, J. B. (2005). Physical Fitness and Academic Achievement. Journal of Exercise Physiology Online, 8(1), 11-25. https://doi.org/10.1519/JSC.0b013e3181874564

[11] Haskell, W. L., Lee, I. M., Pate, R. R., Powell, K. E., Blair, S. N., Franklin, B. A., ... Bauman, A. (2007). Physical activity and public health: Updated recommendation for adults from the American College of Sports Medicine and the American Heart Association. Medicine and Science in Sports and Exercise. https://doi.org/10.1249/mss.0b013e3180616b27

[12] Irianto, Djoko Pekik. 2013. Bugar dan Sehat dengan Berolahraga. Yogyakarta: CV. Andi Offset

[13] Kilpatrick, M., Hebert, E., \& Bartholomew, J. (2005). College students' motivation for physical activity: Differentiating men's and women's motives for sport participation and exercise. Journal of American College Health, 54(2), 87-94. https://doi.org/10.3200/JACH.54.2.87-94

[14] Kyröläinen, H., Santtila, M., Nindl, B. C., \& 
Vasankari, T. (2010a). Physical Fitness Profiles of Young Men. Sports Medicine, 40(11), 907$920 . \quad$ https://doi.org/10.2165/11536570000000000-00000

[15] Kyröläinen, H., Santtila, M., Nindl, B. C., \& Vasankari, T. (2010b). Physical fitness profiles of young men: associations between physical fitness, obesity and health. Sports Medicine (Auckland, N.Z.), 40(11), 907-920. https://doi.org/10.2165/11536570-00000000000000

[16] McGowan \& William P.C. 2011. Menjaga Kebugaran Jantung. Jakarta: PT Raja Grafindo Persada.

[17] Milburn, S., \& Butts, N. K. (1983). A comparison of the training responses to aerobic dance and jogging in college females. Medicine and Science in Sports and Exercise.

[18] Minder, C. M., Shaya, G. E., Michos, E. D., Keenan, T. E., Blumenthal, R. S., Nasir, K., ... Blaha, M. J. (2014). Relation Between SelfReported Physical Activity Level, Fitness, and Cardiometabolic Risk. The American Journal of Cardiology, 113(4), 637-643. https://doi.org/10.1016/j.amjcard.2013.11.010

[19] Ministry of Health of Indonesian Republic. 2012. Guidance to Nurture Physical Fitness. Jakarta: Bakti Husada.

[20] Ministry of Health of Indonesian Republic. 2012. The Improvement of Physical Fitness at Workplaces. Jakarta: Bakti Husada.

[21] Mirkin, C. Hoffman. 1984. Kesehatan Olahraga. Jakarta: PT. Grafika Persada.

[22] Nabkasorn, C., Miyai, N., Sootmongkol, A., Junprasert, S., Yamamoto, H., Arita, M., \& Miyashita, K. (2006). Effects of physical exercise on depression, neuroendocrine stress hormones and physiological fitness in adolescent females with depressive symptoms. European Journal of Public Health, 16(2), 179-184. https://doi.org/10.1093/eurpub/cki159

[23] Pollock, M. L., Feigenbaum, M. S., \& Brechue, W. F. (1995). Exercise prescription for physical fitness. Quest, 47(3), 320-337. https://doi.org/10.1080/00336297.1995.1048416 1

[24] Sadoso, S. 1990. Pengetahuan Praktis Kesehatan dalam Berolahraga. Jakarta: PT. Gramedia Utama Media.

[25] Sharkey, Brian. 2003. Kebugaran dan Kesehatan. PT. Raja Grafindo Persada.

[26] Siconolfi, S. F., Cullinane, E. M., Carleton, R. A., \& Thompson, P. D. (1982). Assessing VO2max in epidemiologic studies: modification of the Astrand-Rhyming test. Med Sci Sports Exerc, 14(5), 335-338.

[27] Siddiqui, N. I., Nessa, A., \& Hossain, M. A.
(2010). Regular physical exercise: way to healthy life. Mymensingh Medical Journal : MMJ, 19(1), 154-158.

[28] Undang-Undang No. 3 Tahun 2005 tentang Sistem Keolahragaan Nasional. Kementerian Pemuda dan Olahraga Republik Indonesia.

[29] Warburton, D. E. R., Nicol, C. W., \& Bredin, S. S. D. (2006). Health benefits of physical activity: the evidence. CMAJ : Canadian Medical Association Journal $=$ Journal de l'Association Medicale Canadienne, 174(6), 801-809. https://doi.org/10.1503/cmaj.051351 